\title{
Ecological Assessment of the Content of Cadmium in Soils and Crops in Southwestern Regions of the Central Chernozemic Zone, Russia
}

\author{
S. V. Lukin ${ }^{a, *}$ and S. V. Selyukova ${ }^{b}$ \\ ${ }^{a}$ Belgorodskii Center of Agrochemical Service, Belgorod, 308027 Russia \\ ${ }^{b}$ Belgorod State Research University, Belgorod, 308015 Russia \\ *e-mail: serg.lukin2010@yandex.ru \\ Received January 18, 2018
}

\begin{abstract}
It is found that in Belgorod oblast during 2010-2014, cadmium mainly came into agrocenoses with organic fertilizers $(0.4 \mathrm{~g} / \mathrm{ha}$, or $73.9 \%)$ and ameliorants $(0.116 \mathrm{~g} / \mathrm{ha}$, or $21.4 \%)$. The lowest total content of cadmium in the A horizon $(0.22 \mathrm{mg} / \mathrm{kg}$ ) was noted in meadow-chernozemic soil (Greyzemic Stagnic Chernic Phaeozem (Clayic, Pachic)) developed on old alluvial calcareous deposits, and its highest content $(0.42 \mathrm{mg} / \mathrm{kg}$ ) was found in ordinary chernozem (Haplic Chernozem (Clayic, Pachic)), where loess-like clay is the main parent rock. Virgin leached chernozem (Luvic Chernozem (Loamic, Pachic)) formed on loesslike loam, contained $0.33 \mathrm{mg} \mathrm{Cd} / \mathrm{kg}$ in the A horizon, which almost coincided with the mean content of this element $(0.32 \mathrm{mg} / \mathrm{kg})$ in the plow layer of leached chernozems on reference plots. No exceeding of the tentative permissible concentration of cadmium was revealed in arable soils. In crops, the content of cadmium was highest in sunflower seeds $(0.086 \mathrm{mg} / \mathrm{kg})$ and soya beans $(0.072 \mathrm{mg} / \mathrm{kg})$, and lowest in peas $(0.032 \mathrm{mg} / \mathrm{kg})$ and white lupine beans $(0.013 \mathrm{mg} / \mathrm{kg})$. The biological adsorption factor varied within the range from 0.97 (while lupine beans) to 10.8 (sunflower seeds) for target agricultural crops and from 0.41 (while lupine straw) to 4.63 (soya straw) for side products.
\end{abstract}

Keywords: chernozem, heavy metal, biological adsorption factor, organic fertilizers, total content

DOI: $10.1134 / \mathrm{S} 1064229318120074$

\section{INTRODUCTION}

In the current Russian agroecology, much attention is given to the contamination of soils with heavy metals (HMs), which is quite explicable, because the level of anthropogenic load on the environment permanently increases. In view of the high spatial variability in the distribution of HMs, the determination of their content in the biosphere components in specific regions remains an important problem [1]. Therefore, the Program of State Agroecological Monitoring implemented by the Agrochemical Service of Russia provides for the study of the content of HMs, including cadmium, in soils and agricultural plants [13, 18].

Cadmium is one of the elements permanently present in plant and animal tissues, but even its small amounts do not participate in any known biochemical process in living organisms (SanPiN 2.3.2.1078-01). According to Vinogradov [2], no information about the physiological significance of the element permanently found in living organisms indicates only chemical problems in their preparation [2].

Cadmium is considered one of the most toxic HMs for living organisms and the most mobile in soils [4, 7, $19,20,27,28]$. At present, its mutagenic, teratogenic, and carcinogenic properties are revealed. By the degree of toxicity, cadmium belongs to hazard class I (highly hazardous substances) (GOST 17.4.1.02-83). However, some authors rightfully affirm that the expression "heavy metal" should be excluded, but the rate and form of compound in which the toxicity of the element is manifested should be indicated [12]. Almost all elements can be toxic when they are present in high contents, and very low concentrations of potentially toxic elements have no harmful effect on soils, plants, and animals $[1,11]$.

Cadmium in plants shows phytotoxicity, which is manifested in the hampering effect on photosynthesis, disturbance of transpiration and $\mathrm{CO}_{2}$ fixation, and inhibition of biochemical processes in microorganisms. The high phytotoxicity of cadmium is due to the similarity of its chemical properties to those of zinc. Therefore, cadmium can double zinc in many geochemical processes and disturb the functions of some enzymes. In the presence of an excess amount of this element in plants, the contents of phosphorus, calcium, magnesium, iron, and zinc decrease $[1,11,19]$. According to the authors studying the signs of toxicity in agricultural plants, cadmium is more toxic than other metals in 2-20 times [8]. Signs of cadmium toxicity vary among plant species: leaf chlorosis (which is 
a common characteristic sign), appearance of purple color, leaf rolling, and growth inhibition [22].

The highest content of cadmium is localized in roots, and significantly lower contents are found in aboveground plant organs, especially generative organs; i.e., a selective distribution is observed because of the presence of several barriers limiting the input of the toxic element with the upward flux of matter [11].

Permissible contents of this element in agricultural raw materials and tentative maximum permissible contents in fodders for agricultural animals are established in Russia. For example, the permissible level for food grain is $0.1 \mathrm{mg} / \mathrm{kg}$ (under standard water content), and the maximum permissible level for fodder grain is $0.3 \mathrm{mg} / \mathrm{kg}$ [5, SanPiN 2.3.2.1078-01].

Tentative permissible concentrations (TPCs) are established for the regulation of total cadmium content in soils. In contrast to maximum permissible concentrations (MPCs), TPCs are established by calculation rather than experimentally. The TPC of cadmium is $0.5 \mathrm{mg} / \mathrm{kg}$ in sandy and loamy sandy soils; in loamy and clayey soils with $\mathrm{pH}<5.5$, this value doubles and reaches $1 \mathrm{mg} / \mathrm{kg}$; in soils with $\mathrm{pH}>5.5$, the value doubles again and reaches $2 \mathrm{mg} / \mathrm{kg}$ (Hygienic Norms GN 2.1.7.2511-09).

Russian Regulations establish no MPC or TPC for mobile cadmium in soils. From the results of experimental studies, the value corresponding to the contamination of the least tolerant agricultural crop $(0.7 \mathrm{mg} / \mathrm{kg}$ soil) can be reasonably taken as the MPC of mobile cadmium forms in chernozemic soils [25].

The aim of this work was the ecological assessment of cadmium content in soils and plants of the Central Chernozemic Zone of Russia. To reach the aim set, three main tasks were solved: to study the main sources of cadmium input into the soils and the formation features of the element balance in agrocenoses, to assess the distribution of cadmium in arable and virgin soils of the region, and to assess the content of cadmium in virgin plants and major agricultural crops.

\section{OBJECTS AND METHODS}

Studies were fulfilled in the forest-steppe zone of Belgorod oblast, Central Chernozemic Zone. Data of local agroecological monitoring, which was performed on 20 reference plots of the forest-steppe zone in 2010-2017, were used. Reference plots were established in each administrative district of the oblast; these were fields or parts of a field 4-40 ha in area ${ }^{1}$. The soil of reference plots consists of leached chernozem (Luvic Chernozem (Loamic, Pachic)). In the 0to $20-\mathrm{cm}$ layer, the mean content of available phosphorus determined by the Chirikov method was

\footnotetext{
${ }^{1}$ Methodological Guidelines on the Determination of Heavy Metals in Agricultural Soils and Crops. Moscow, 1992 (in Russian).
}

$139 \mathrm{mg} / \mathrm{kg}$, and the content of exchangeable potassium was $119 \mathrm{mg} / \mathrm{kg}$. The content of total exchangeable bases was $39.8 \mathrm{cmeq} / \mathrm{kg}$ soil; $\mathrm{pH}_{\mathrm{KCl}}$ was $5.3 ; \mathrm{pH}_{\mathrm{H}_{2} \mathrm{O}}$ was 6.4 . The content of organic matter by the Tyurin method was $5.3 \%$.

The total cadmium content $\left(5 \mathrm{M} \mathrm{HNO}_{3}\right.$ as extractant) and the concentration of mobile element forms in the soil extractable by ammonium acetate buffer with pH 4.8 were determined by atomic emission spectroscopy according to M-MVI-80, 2008. The total element content in organic fertilizers and crops was determined by common procedures for agrochemical service ${ }^{2}$.

Statistical processing of local monitoring data was performed using the confidence interval for the mean values $\left(\bar{x} \pm t_{05} s \bar{x}\right)$ and the coefficient of variations $(V, \%)$.

The selective adsorption of chemical elements by agricultural crops was characterized by the biological adsorption factor, which is calculated as the ratio between the element content in plant ash and its content in the arable soil layer.

\section{RESULTS AND DISCUSSION}

Sources of cadmium input into the soil. The main sources of soil contamination with cadmium in the European Union countries are emissions from zinccadmium ( $60 \%$ of total contamination) and coppernickel $(23 \%)$ smelters, as well as the burning of fuel $(10 \%)$ and gasoline $(3 \%)$. The other contamination sources make up 4\% [26]. In Belgorod oblast, these are no similar enterprises; therefore, fertilizers and ameliorants are the main sources of cadmium input into the soil.

Russian mineral fertilizers should not be considered as an important source of soil contamination with cadmium. From our data, the content of cadmium is $0.04 \mathrm{mg} / \mathrm{kg}$ in ammonium nitrate and $0.10 \mathrm{mg} / \mathrm{kg}$ in azophoska (nitrogen-phosphorus-potassium fertilizer). Khibiny apatites, which serve as raw material for phosphoric fertilizers, contain little cadmium. However, in some foreign countries, including Australia and China, cadmium present in phosphoric fertilizers is an important source of soil contamination [29, 30].

The main sources of HM input into agrocenoses include organic fertilizers, which strongly vary in the content and proportions of elements. The mean concentrations of cadmium in cattle manure, strawchicken manure compost, and manure effluents are $0.84,0.153$, and $0.008 \mathrm{mg} / \mathrm{kg}$, respectively (Table 1 ).

About $3.3 \mathrm{t}$ of straw-chicken manure compost, $13.2 \mathrm{t}$ cattle manure, or $47.6 \mathrm{t}$ manure effluents are needed to add $100 \mathrm{~kg} \mathrm{~N} /$ ha with organic fertilizers. With these amounts of organic fertilizers, $0.50,1.11$,

\footnotetext{
${ }^{2}$ Sychev V.G. et al. (ed). Methodological Guidelines for Local Monitoring on Reference and Control Plots. Rosinformagrotekh, Moscow, 2006 (in Russian).
} 
Table 1. Cadmium in organic fertilizers and defecate, $\mathrm{mg} / \mathrm{kg}$

\begin{tabular}{l|c|c|c|c}
\hline \multicolumn{1}{c|}{ Fertilizer (\% of dry matter) } & $n$ & $\bar{x} \pm t_{05} \mathrm{~s} \bar{x}$ & Range & $V, \%$ \\
\hline Manure effluents (2.22) & 23 & $0.008 \pm 0.001$ & $0.003-0.012$ & 31.9 \\
Straw-chicken manure compost (56) & 20 & $0.153 \pm 0.027$ & $0.071-0.257$ & 37.9 \\
Cattle manure (25) & 20 & $0.084 \pm 0.014$ & $0.038-0.139$ & 36.3 \\
Defecate (87) & 30 & $0.297 \pm 0.022$ & $0.195-0.405$ & 20.0 \\
\hline
\end{tabular}

and $0.38 \mathrm{~g} \mathrm{Cd} /$ ha will be added to the soil, respectively. In the Central Chernozemic Zone, some amount of HMs gets into the soil with defecate (waste from sugar mills), which is widely used as ameliorant in liming acid soils. The mean content of cadmium in defecate is $0.297 \mathrm{mg} / \mathrm{kg}$.

In $2010-2014,4.82 \mathrm{t} / \mathrm{ha}$ organic fertilizers (in terms of cattle manure) were applied on the average in Belgorod oblast, as well as $97.9 \mathrm{~kg}$ a.i./ha mineral fertilizers and $0.39 \mathrm{t} / \mathrm{ha}$ ameliorant. During this period, cadmium mainly came into agrocenoses with organic fertilizers $(0.4 \mathrm{~g} / \mathrm{ha}$, or $73.9 \%)$ and ameliorants $(0.116 \mathrm{~g} / \mathrm{ha}$, or $21.4 \%)$. We estimate the input of element as only $0.017 \mathrm{~g} / \mathrm{ha}(3.1 \%)$ with mineral fertilizers and as $0.008 \mathrm{~g} / \mathrm{ha}(1.6 \%)$ with seeds.

Water erosion is one of the main types of arable soil degradation in Belgorod oblast. About 3235000 t soil (1.92 $t$ per conventional hectare of plowland) is lost in the oblast annually, as well as some amounts of macroand microelements [21]. The withdrawal of cadmium from agrocenoses mainly occurred together with the lost soil $(0.61 \mathrm{~g} / \mathrm{ha}$, or $74.4 \%)$ and with crop, although in a significantly smaller amounts $(0.21 \mathrm{~g} / \mathrm{ha}$, or $25.6 \%)$. In general, a negative balance of cadmium was created $(-0.279 \mathrm{~g} / \mathrm{ha})$. The balance intensity (ratio between the input and output items expressed in percentage) was $66 \%$.

Content of cadmium in soils. According to Vinogradov [3], the clarke (natural abundance) of total cadmium content in soils is $0.5 \mathrm{mg} / \mathrm{kg}$. From current estimations, the element clarke in the world soils is $0.41 \mathrm{mg} / \mathrm{kg}$ [24]. The variation range of this element in soils is relatively wide. For example, some authors estimate it as $0.01-0.7 \mathrm{mg} / \mathrm{kg}$ [23]. The variation range of total cadmium is estimated as $0.01-2.31 \mathrm{mg} / \mathrm{kg}$ in soddy-podzolic soils of Russia, $0.03-0.7 \mathrm{mg} / \mathrm{kg}$ in gray forest soils, $0.75-1.15 \mathrm{mg} / \mathrm{kg}$ in alluvial soils, and $0.01-1.0 \mathrm{mg} / \mathrm{kg}$ in chernozems $[6,9,10,16,17,19]$. Cadmium is most mobile in acid soils $\left(\mathrm{pH}_{\mathrm{KCl}} 4.5-5.5\right)$, while it is relatively immobile in alkaline soils. In soils, cadmium can disturb the fixation of atmospheric nitrogen and reduce the intensity of ammonification, nitrification, and denitrification [15].

Cadmium in uncontaminated soils is present in amounts determined by its content in the parent rock. Among the parent rocks, the highest cadmium content is typical for clays, clay shales, and loesses, and the lowest content is typical for sands and loamy sands.
Meadow-chernozemic soils (Greyzemic Stagnic Chernic Phaeozems (Clayic, Pachic)) developed on old alluvial calcareous deposits containing 54.8\% physical clay are characterized by the lowest total cadmium content in the humus-accumulative horizon $(0.22 \mathrm{mg} / \mathrm{kg})$. Virgin leached chernozem of the Yamskaya Step reserved plot, which is developed on loess-like loam with $59.4 \%$ physical clay, contains $0.33 \mathrm{mg} / \mathrm{kg}$ cadmium in the A horizon (Table 2). The lowest total cadmium content $(0.42 \mathrm{mg} / \mathrm{kg})$ is observed in ordinary chernozem (Haplic Chernozem (Clayic, Pachic)), where loess-like clay with $73.6 \%$ physical clay is the parent rock.

Local monitoring data showed that the mean total cadmium content in the plow layer of soils on the reference plots of Belgorod oblast is $0.32 \mathrm{mg} / \mathrm{kg}$, which is lower than the element clarke in soils (Table 3 ). The total cadmium content reliably decreases with depth. This can be related to the biophilous accumulation of the element in the humus horizon. No exceeding of the element TPC is noted.

The background content of mobile cadmium forms in the A1 horizon of leached chernozem on the Yamskaya Step reserved plot is $0.07 \mathrm{mg} / \mathrm{kg}$, which almost coincides with its content in the $0-$ to $20-\mathrm{cm}$ layer of arable chernozems. On the reference plots, the content of mobile cadmium forms does not change with depth; it is $21.9-31.0 \%$ of the total amount.

Content of cadmium in plants. The chemical composition of each plant species is related with the chemical composition of the environment, in which the species was developed. The combinations and concentrations of the elements, which are predominant in soils of the area of species formation, came into the organisms, were fixed by evolutional selection, and were inherited. Therefore, the chemical composition of plants can retain signs of the chemical composition of the original environment [1].

The content of cadmium in agricultural plants varies in a very wide range depending on the biological features of the species and cultivar, element concentration in soils, chemicals used, etc. The mean content of cadmium is estimated as $0.12 \mathrm{mg} / \mathrm{kg}$ in cereal crops and $0.33 \mathrm{mg} / \mathrm{kg}$ in legumes [11]. From the generalized data, the content of this metal is within the range $0.02-0.38 \mathrm{mg} / \mathrm{kg}$ dry matter in barley plants and $0.04-3.9 \mathrm{mg} / \mathrm{kg}$ in corn plants [28]. 
Table 2. Cadmium in soils of Belgorod oblast, $\mathrm{mg} / \mathrm{kg}$

\begin{tabular}{l|c|c|c|c}
\hline \multicolumn{1}{c|}{ Horizon } & Horizon depth, cm & Sampling depth, cm & Total & Mobile forms \\
\hline \multicolumn{4}{c|}{ Meadow-chernozemic soil (village of Blizhnyaya Igumenka, Belgorod district) } \\
$\mathrm{A}$ & $5-45$ & $20-30$ & 0.22 & 0.06 \\
$\mathrm{AB}$ & $45-72$ & $55-65$ & 0.22 & 0.02 \\
$\mathrm{~B}$ & $72-90$ & $75-85$ & 0.21 & 0.01 \\
$\mathrm{BC}$ & $90-125$ & $100-110$ & 0.22 & 0.08 \\
$\mathrm{C}$ & $125-160$ & $140-150$ & 0.22 & 0.05 \\
\multicolumn{1}{|c|}{ Deep fertile leached chernozem (Yamskaya Step plot) } \\
$\mathrm{A}_{1}$ & $7-45$ & $10-20$ & 0.33 & 0.07 \\
$\mathrm{AB}$ & $46-68$ & $50-60$ & 0.37 & 0.05 \\
$\mathrm{~B}$ & $69-90$ & $70-80$ & 0.37 & 0.10 \\
$\mathrm{BC}$ & $91-120$ & $100-110$ & 0.35 & 0.08 \\
$\mathrm{C}$ & $121-165$ & $140-150$ & 0.33 & 0.08 \\
& Medium-humus ordinary chernozem (Roven'skii natural park) & \\
$\mathrm{A}_{\text {ca }}$ & $5-35$ & $15-25$ & 0.42 & 0.06 \\
$\mathrm{~B}_{\text {ca }}$ & $35-55$ & $40-50$ & 0.46 & 0.06 \\
$\mathrm{BC}_{\text {ca }}$ & $55-83$ & $65-75$ & 0.43 & 0.06 \\
$\mathrm{C}_{\text {ca }}$ & $83-150$ & $110-120$ & 0.43 & 0.06 \\
\hline
\end{tabular}

Table 3. Variation-statistical parameters of cadmium content in leached chernozem, $\mathrm{mg} / \mathrm{kg}$

\begin{tabular}{l|c|c|c|c|c}
\hline \multirow{2}{*}{ Parameter } & \multicolumn{5}{c}{ Soil layer, cm } \\
\cline { 2 - 6 } & $0-20$ & $21-40$ & $41-60$ & $61-80$ & $81-100$ \\
\hline \multirow{3}{*}{$\bar{x} \pm t_{05} s \bar{x}$} & $0.32 \pm 0.01$ & $0.32 \pm 0.01$ & $0.31 \pm 0.01$ & $0.31 \pm 0.01$ & $0.29 \pm 0.01$ \\
Range & $0.28-0.36$ & $0.27-0.36$ & $0.26-0.33$ & $0.26-0.36$ & $0.24-0.36$ \\
$V, \%$ & 6.9 & 7.3 & 5.7 & 8.1 & 9.7 \\
$\bar{x} \pm t_{05} s \bar{x}$ & $0.08 \pm 0.01$ & $0.07 \pm 0.01$ & $0.08 \pm 0.01$ & $0.07 \pm 0.01$ & $0.09 \pm 0.01$ \\
Range & $0.06-0.14$ & $0.0-0.10$ & $0.05-0.11$ & $0.0-0.11$ & $0.06-0.12$ \\
$V, \%$ & 19.9 & 29.4 & 21.0 & 35.0 & 19.6 \\
\hline
\end{tabular}

In the virgin steppe herbs (with the dominance of feather grass, sheep fescue, June grass), the mean content of cadmium was $0.053 \mathrm{mg} / \mathrm{kg}$. From the results of local agroecological monitoring, sunflower was characterized by the highest background content of cadmium among the studied agricultural crops. The mean content of cadmium in its seeds was $0.086 \mathrm{mg} / \mathrm{kg}$, which was more than double that in wheat or corn grain $(0.042 \mathrm{mg} / \mathrm{kg})$. The mean content of the element in soya beans was slightly lower $(0.072 \mathrm{mg} / \mathrm{kg})$. Lowest contents of the element were found in peas $(0.032 \mathrm{mg} / \mathrm{kg})$ and white lupine beans $(0.013 \mathrm{mg} / \mathrm{kg})$. According to the content of cadmium in the main product, the studied cultures form the following decreasing series: sunflower $>$ soya $>$ corn, winter wheat $>$ sugar beet $>$ barley $>$ pea $>$ white lupine.
In the side products of winter wheat, barley, sugar beet, corn, and soya, the content of cadmium was higher than in the main products in $1.31,1.36,1.83$, 1.40 , and 1.15 times, respectively. In the side products of pea, white lupine, and sunflower, the content of cadmium was higher than in the main products in $1.45,1.63$, and 1.23 times, respectively. According to the cadmium content in the side products, the cultures form the following decreasing series: soya $>$ sugar beet $>$ sunflower $>$ corn $>$ winter wheat $>$ barley $>$ pea $>$ white lupine (Table 4 ).

For the lack of data characterizing the tolerance of agricultural crops to the high concentrations of this toxicant in chernozemic soils, microfield model experiments were performed in Belgorod oblast. It was 
Table 4. Variation-statistical parameters of cadmium content in plants, $\mathrm{mg} / \mathrm{kg}$ oven-dry material

\begin{tabular}{|c|c|c|c|c|c|}
\hline \multicolumn{2}{|c|}{ Crop } & $n$ & $\bar{x} \pm t_{05} s \bar{x}$ & Range & $V, \%$ \\
\hline \multirow[t]{2}{*}{ Winter wheat } & Grain & 46 & $0.042 \pm 0.004$ & $0.020-0.070$ & 33.0 \\
\hline & Straw & 46 & $0.055 \pm 0.006$ & $0.022-0.085$ & 33.1 \\
\hline \multirow[t]{2}{*}{ Barley } & Grain & 37 & $0.039 \pm 0.005$ & $0.024-0.067$ & 34.9 \\
\hline & Straw & 37 & $0.053 \pm 0.006$ & $0.019-0.084$ & 34.8 \\
\hline \multirow[t]{2}{*}{ Sugar beet } & Roots & 23 & $0.040 \pm 0.006$ & $0.024-0.072$ & 33.4 \\
\hline & Tops & 23 & $0.073 \pm 0.008$ & $0.020-0.102$ & 26.5 \\
\hline \multirow[t]{2}{*}{ Pea } & Beans & 20 & $0.032 \pm 0.005$ & $0.012-0.049$ & 33.0 \\
\hline & Straw & 20 & $0.022 \pm 0.003$ & $0.011-0.032$ & 29.2 \\
\hline \multirow[t]{2}{*}{ White lupine } & Beans & 20 & $0.013 \pm 0.002$ & $0.006-0.019$ & 26.9 \\
\hline & Straw & 20 & $0.008 \pm 0.001$ & $0.005-0.011$ & 22.0 \\
\hline \multirow[t]{2}{*}{ Corn } & Grain & 21 & $0.042 \pm 0.006$ & $0.016-0.054$ & 29.4 \\
\hline & Straw & 21 & $0.059 \pm 0.005$ & $0.051-0.088$ & 16.7 \\
\hline \multirow[t]{2}{*}{ Soya } & Beans & 22 & $0.072 \pm 0.005$ & $0.017-0.097$ & 25.7 \\
\hline & Straw & 22 & $0.083 \pm 0.005$ & $0.033-0.106$ & 19.8 \\
\hline \multirow[t]{2}{*}{ Sunflower } & Seeds & 20 & $0.086 \pm 0.009$ & $0.073-0.162$ & 21.4 \\
\hline & Stems & 20 & $0.070 \pm 0.003$ & $0.060-0.079$ & 8.4 \\
\hline Steppe herbs & & 20 & $0.053 \pm 0.001$ & $0.048-0.059$ & 5.4 \\
\hline
\end{tabular}

Table 5. Mean cadmium content in plant ash and biological adsorption factors

\begin{tabular}{|c|c|c|c|c|}
\hline \multicolumn{2}{|c|}{ Crop } & \multirow{2}{*}{$\begin{array}{c}\text { Mean ash content, \%dry } \\
\text { matter }\end{array}$} & \multirow{2}{*}{$\begin{array}{c}\begin{array}{c}\text { Mean content in plant ash, } \\
\mathrm{mg} / \mathrm{kg} \text { ash }\end{array} \\
1.91\end{array}$} & \multirow{2}{*}{\begin{tabular}{|c|}
$\begin{array}{c}\text { Biological adsorption factor, } \\
\text { (mg/kg ash)/(mg/kg soil) }\end{array}$ \\
5.97
\end{tabular}} \\
\hline Winter wheat & $\begin{array}{l}\text { Grain } \\
\text { Straw }\end{array}$ & & & \\
\hline \multirow[t]{2}{*}{ Barley } & Grain & 3.0 & 1.30 & 4.06 \\
\hline & Straw & 6.75 & 0.79 & 2.50 \\
\hline \multirow[t]{2}{*}{ Sugar beet } & Roots & 2.7 & 1.48 & 4.63 \\
\hline & Tops & 16.4 & 0.45 & 1.41 \\
\hline \multirow[t]{2}{*}{ Pea } & Beans & 3.1 & 1.03 & 3.22 \\
\hline & Straw & 8.0 & 0.28 & 0.88 \\
\hline \multirow[t]{2}{*}{ White lupine } & Beans & 4.2 & 0.31 & 0.97 \\
\hline & Straw & 6.2 & 0.13 & 0.41 \\
\hline \multirow[t]{2}{*}{ Corn } & Grain & 1.5 & 2.80 & 8.75 \\
\hline & Straw & 7.3 & 0.81 & 2.53 \\
\hline \multirow[t]{2}{*}{ Soya } & Beans & 5.2 & 1.38 & 4.31 \\
\hline & Straw & 5.6 & 1.48 & 4.63 \\
\hline \multirow[t]{2}{*}{ Sunflower } & Seeds & 2.5 & 3.44 & 10.8 \\
\hline & Stems & 5.1 & 1.37 & 4.28 \\
\hline Steppe herbs & & & 0.83 & 2.52 \\
\hline
\end{tabular}

found that when the content of mobile cadmium forms in the soil increased from 0.35 to $2.5 \mathrm{mg} / \mathrm{kg}$, the concentration of this toxicant increased from 0.057 to $0.136 \mathrm{mg} / \mathrm{kg}$ in barley grain, from 0.089 to $0.209 \mathrm{mg} / \mathrm{kg}$ in buckwheat grain, and from 0.076 to $0.364 \mathrm{mg} / \mathrm{kg}$ in wheat grain [25].

Cadmium can be characterized as an element of high adsorption intensity. The factor of biological adsorption of the element by steppe herbs was 2.52 .
The biological adsorption factor was within the range from 0.97 (white lupine beans) to 10.8 (sunflower seeds) for the main products and from 0.41 (white lupine straw) to 4.63 (soya straw) for side products. The coefficient of biological adsorption of cadmium for the main products was higher than for side products for all cultures, except soya, which was primarily related to the higher ash content in side products (Table 5). 
For the mean yield of winter wheat $(3.5 \mathrm{t} / \mathrm{ha}$ at a standard water content of $14 \%$ ), which was in Belgorod oblast in 2010-2014, the total cadmium removal with crop was $0.13 \mathrm{~g} / \mathrm{ha}$ (together with straw, $0.37 \mathrm{~g} / \mathrm{ha}$ ). At the barley grain yield of $3 \mathrm{t} / \mathrm{ha}$, the cadmium removal was $0.1 \mathrm{~g} / \mathrm{ha}$ (together with straw, $0.26 \mathrm{~g} / \mathrm{ha}$ ); the sugar beet yield of $35 \mathrm{t} / \mathrm{ha}$ removed $0.35 \mathrm{~g} / \mathrm{ha}$ cadmium (together with tops, $0.73 \mathrm{~g} / \mathrm{ha}$ ); the corn grain yield of $5 \mathrm{t} / \mathrm{ha}$ removed $0.18 \mathrm{~g} / \mathrm{ha}$ cadmium (together with side products, $0.68 \mathrm{~g} / \mathrm{ha}$ ); the soya grain yield of $1.6 \mathrm{t} / \mathrm{ha}$ removed $0.10 \mathrm{~g} / \mathrm{ha}$ cadmium (together with side products, $0.23 \mathrm{~g} / \mathrm{ha}$ ); the sunflower seed yield of $2.0 \mathrm{t} / \mathrm{ha}$ removed $0.16 \mathrm{~g} / \mathrm{ha}$ cadmium (together with side products, $0.63 \mathrm{~g} / \mathrm{ha}$ );

\section{CONCLUSIONS}

New data characterizing cadmium balance parameters have been obtained. In Belgorod oblast during 2010-2014, cadmium mainly came into agrocenoses with organic fertilizers $(0.4 \mathrm{~g} / \mathrm{ha}$, or $73.9 \%)$ and ameliorants $(0.116 \mathrm{~g} / \mathrm{ha}$, or $21.4 \%)$. In general, a negative balance of cadmium was created $(-0.279 \mathrm{~g} / \mathrm{ha})$.

The lowest total content of cadmium in the A horizon $(0.22 \mathrm{mg} / \mathrm{kg})$ was noted in meadow-chernozemic soil (Greyzemic Stagnic Chernic Phaeozem (Clayic, Pachic)) developed on old alluvial calcareous deposits, and its highest content $(0.42 \mathrm{mg} / \mathrm{kg})$ was found in ordinary chernozem (Haplic Chernozem (Clayic, Pachic)), where loess-like clay is the main parent rock. Virgin leached chernozem (Luvic Chernozem (Loamic, Pachic)) formed on loess-like loam, contained $0.33 \mathrm{mg} \mathrm{Cd} / \mathrm{kg}$ in the A horizon, which almost coincided with the mean content of this element $(0.32 \mathrm{mg} / \mathrm{kg})$ in the plow layer of leached chernozems on reference plots.

In crop products, the mean content of cadmium was highest in sunflower seeds $(0.086 \mathrm{mg} / \mathrm{kg})$ and soya beans $(0.072 \mathrm{mg} / \mathrm{kg})$ and lowest in peas $(0.032 \mathrm{mg} / \mathrm{kg})$ and white lupine beans $(0.013 \mathrm{mg} / \mathrm{kg})$. The biological adsorption factor varied within the range from 0.97 (while lupine beans) to 10.8 (sunflower seeds) for the main products of agricultural crops and from 0.41 (while lupine straw) to 4.63 (soya straw) for side products.

No exceeding of the cadmium TPC was revealed in the studied soils or in crops.

\section{REFERENCES}

1. Yu. V. Alekseev, Heavy Metals in Soils and Plants (Agropromizdat, Leningrad, 1987) [in Russian].

2. A. P. Vinogradov, "General regularities of redistribution of trace elements between the plants and the environment," in Trace Elements in the Plants and Animals (Academy of Sciences of the Soviet Union, Moscow, 1952), pp. 7-20.
3. A. P. Vinogradov, Geochemistry of Rare and Dispersed Chemical Elements in Soils (Academy of Sciences of USSR, Moscow, 1957) [in Russian].

4. Yu. N. Vodyanitskii, "Standards for the contents of heavy metals and metalloids in soils," Eurasian Soil Sci. 45, 321-328 (2012).

5. Temporal Maximum Permissible Level (MPL) of Some Chemical Elements and Gossypol in Fodder for Agricultural Animals and Food Supplements (State Agroindustrial Committee of USSR, Moscow, 1987) [in Russian].

6. Geochemistry of the Environment, Ed. by Yu. E. Saet, (Nedra, Moscow, 1990) [in Russian].

7. A. P. Endovitskii, V. P. Kalinichenko, and T. M. Minkina, "Lead and cadmium in chernozem after application of phosphogypsum," Pochvovedenie, No. 3, 340350 (2014). doi 10.7868/S0032180X14030058

8. N. G. Zyrin and L. K. Sadovnikova, Chemistry of Heavy Metals, Arsenic, and Molybdenum in Soils (Moscow State Univ., Moscow, 1985) [in Russian].

9. B. R. Zolotareva and I. I. Skripnichenko, "The content and distribution of heavy metals (lead, cadmium, and mercury) in soils of the European part of the Soviet Union," in Genesis, Fertility, and Melioration of Soils (Pushchino, 1980), pp. 77-90.

10. L. A. Izerskaya and T. E. Vorob'eva, "Heavy metal compounds in alluvial soils of the Middle Ob Valley," Eurasian Soil Sci. 33, 49-55 (2002).

11. V. B. Il'in, Heavy Metals in the Soil-Plant System (Nauka, Novosibirsk, 1991) [in Russian].

12. V. V. Koval'skii, Yu. I. Raetskaya, and T. I. Gracheva, Trace Elements in the Plants and Fodders (Kolos, Moscow, 1971) [in Russian].

13. Red Data Book of Belgorod Oblast, Ed. by V. D. Solovichenko, (Belgorod State Univ., Belgorod, 2007) [in Russian].

14. V. G. Mineev, Chemization of Agriculture and the Environment (Agropromizdat, Moscow, 1990).

15. C. Răuță and S. Cârstea, Prevenirea şi Combaterea Poluării Solului (Editura Ceres, Bucharest, 1983; Agropromizdat, Moscow, 1986).

16. M. S. Sokolov, et al., "Evaluation of pollution of agrolandscapes in the North Caucasus and mitigation of its negative consequences," Agrokhimiya, No. 2, 84-96 (1996).

17. A. I. Fateev and M. N. Lysenko, "Transformation of heavy metals in soils with different buffer capacity," in Heavy Metals and Radionuclides in Agroecosystems (Moscow State Univ., Moscow, 1994), pp. 137-139.

18. E. A. Cherkasov, A. Kh. Kulikova, and D. A. Lobachev, "Dynamics of soil fertility in Ulyanovsk oblast in 19652015," Dostizh. Nauki Tekh. APK, No. 4, 10-17 (2017).

19. N. A. Chernykh, N. Z. Milashchenko, and V. F. Ladonin, Ecotoxicological Aspects of Soil Pollution by Heavy Metals (Agrokonsalt, Moscow, 1999) [in Russian].

20. G. D. Chimitdorzhieva, A. Z. Nimbueva, and E. A. Bodeeva, "Heavy metals (copper, lead, nickel, and cadmium) in the organic part of gray forest soils in the Buryat Republic," Eurasian Soil Sci. 45, 141-146 (2012).

21. I. S. Shatilov, A. D. Silin, and N. A. Polev, "Improvement of soil fertility in the central chernozemic economic region of the Russian Federation," in Proceed- 
ings of Joint Meeting of the Presidium of the All-Union Lenin Academy of Agricultural Sciences and its Russian Branch "Improvement of the Efficiency of Agriculture and Agroindustry in Belgorod Oblast, " Belgorod, June 6-7, 1989 (Rosagropromizdat, Moscow, 1990), pp. 33-43.

22. B. A. Yagodin, S. B. Vinogradova, and V. V. Govorina, "Cadmium in the soil-fertilizer-plant-living organisms system," Agrokhimiya, No. 5, 125-135 (1989).

23. H. J. Bowen, Trace Elements in Biochemistry (Academic, New York, 1966).

24. A. Kabata-Pendias, Trace Elements in Soils and Plants (CRC Press, Boca Raton, 2011).

25. S. V. Lukin, I. E. Soldat, and V. E. Yavtushenko, "Cadmium accumulation in agricultural crops dependent on the soil contamination level," Eurasian Soil Sci. 33, 91-95 (2000).

26. J. M. Pacyna, A. Semb, and J. E. Hanssen, Emission and long-range transport of trace-elements in Europe," Tellus B 36 (3), 163-178 (1984).
27. C. P. Rooney, R. G. Laren, and L. M. Condron, "Control of lead solubility in soil contaminated with lead shot," in Proceedings of 7th International Conference on the Biogeochemistry of Trace Elements, Abstracts of Papers (Uppsala, 2003), Vol. 1, pp. 116-117.

28. H. L. Schnetzer, A. Chetelat, and J.-M. Besson, "Auswirkung von Klarschlamm and Klarchlamm kompost auf den Schwermetallgehalt von Futterpflanzen im Gefapversuch," Landwirschaftliche Forchung. 36, 343-352 (1980).

29. Q. Wang, Y. Dong, Y. Cui, and X. Liu, "Instances of soil and crop heavy metals contamination in China," Soil Sediment. Contam. 10, 497-510 (2001).

30. C. H. Williams and D. J. David, "The effect of superphosphate on cadmium content of soils and plant," Austr. J. Soil Res. 11, 43-56 (1973).

Translated by K. Pankratova 